\title{
How Globalization has Changed Diplomacy
}

\author{
Sophie Nanyonga \\ Ankara Yildirim Beyazit University, Ankara, Turkey, sophiananyonga@yahoo.com
}

\begin{abstract}
Globalization, which refers to the changes in time and space is perhaps one of the most significant events in this century. It has brought with it, unique changes in communication, trade, mobility, international security, and migration. Some have argued that its impact has further weakened the place and role of the state in international politics, given many actors who have emerged in this process. This paper seeks to examine how the changes in time and space are affecting diplomatic relations among states. While it is true that several actors are today playing some roles previously reserved for the state, the field of diplomacy seems to have been protected from non-state actors as government representatives still dominate diplomatic channels. By looking at events such as the Gulf Cooperation Council's role in the Yemen Political crisis and Economic Community of West African States' (ECOWAS) role in Gambia's political turmoil, a new form of regionalized diplomacy is seen. The case of the Syrian crisis also has realized a shift from bilateral to multilateral diplomacy. The writer argues that the changes in space have had little effect on diplomacy but rather the changes in time, largely associated with the rapid flow of information have transformed how diplomacy is practiced today. The paper adopts a qualitative research approach and relies on data from secondary sources like textbooks, among others.
\end{abstract}

KEYWORDS: diplomacy, globalization, international relations, integration, communication

\section{Introduction}

Diplomacy is as old as humanity itself, and one cannot, therefore, claim its date of evolution. From the first human relations, diplomacy has existed, because fundamentally, it is about relationships. Diplomacy can also be defined as the profession, activity, or skill of managing International relations, typically by a country's representative abroad. Globalization, on the other hand, is believed to have emerged at the end of the Cold War with the breaking down of borders and the opening of systems to greater inter-dependence, fueled by the two forces of economic liberalization and technology outburst (Campbell 2015, 20). It is however clear that this post-Cold War era is just an era of the latest phase of globalization. Therefore, one could argue that globalization, like diplomacy, has always existed but only felt in the post-Cold War era since this phase of globalization is the most advanced.

In international relations, various scholars have defined diplomacy in different ways, but the entire definitions sum up to the art of dealing with people/states in a sensitive, organized and tactful way through negotiations and agreements. In another instance, diplomacy was defined as the means through which a political activity enables actors to pursue their objectives and defend their interests through negotiations, with no use of force, propaganda or law (Berridge 2005,1). The art of diplomacy consists of communication between entities designed to achieve agreements, be it formal or informal; implied or explicit. Such communication and its achievements can be facilitated by gathering information, clarifying intentions, and promoting goodwill. Diplomacy, therefore, can be viewed as an alternative foreign policy to maintain peace and stability in the international arena.

Modern diplomacy which involves the sending of emissaries on the other hand is traced to some parts of Northern Italy in the early Renaissance, where the first embassies were established in the Thirteenth century (Berridge 2010,1). Francesco Sforza in Milan played a leading role by establishing permanent embassies to the other city-states of Northern Italy (Neumann 2012, 16-17). It was in Italy, therefore that many of the traditions of modern diplomacy began, such as the presentation of an ambassador's credentials to the head of state.

To some scholars, modern-day diplomacy was born in the $17^{\text {th }}$ century through The Peace of Westphalia, which established the precedent of peace established by a diplomatic congress. Signed in 1648, it created the first modern diplomatic congress and new world order in central Europe based on state 
sovereignty (Colegrove 1919, 450-482). The Congress of Vienna of 1815 was, however, the first official treaty to establish an international system on diplomatic relations. The 1815 Congress of Vienna was also the first of a series of international meetings that came to be known as the Concert of Europe, which aimed at creating a peaceful balance of power in Europe (Rie 1950,209). It is not surprising therefore that this same treaty later served as a model for later organizations such as the League of Nations in 1919 that subsequently transformed into the United Nations in 1945.

The Vienna Convention on Diplomatic Relations of 1961 (that shall hereafter be referred to as The Convention) which is an international treaty that defines a framework for diplomatic relations between independent countries doesn't specifically define diplomacy but if read in whole, one understands clearly what diplomacy means according to the international treaties.

Ideally, in international politics, diplomacy is officially carried out by a diplomatic agent- a representative chosen by the sending state normally referred to as an ambassador and in some cases a consular. Article 1 (e) of The Vienna Convention defines a diplomatic agent as the head of the mission or a member of the diplomatic staff of the mission. It states that; "Diplomatic agent" is the head of the mission or $\dot{a}$ member of the diplomatic staff of the mission.;"

The convention further states in Article 2 that the establishment of diplomatic relations between States, and permanent diplomatic missions, shall take place by mutual consent between parties intending to create such a relation. Diplomacy is generally about representing states, gathering information and expansion of political, economic, and cultural ties between states. All this is done by facilitating, enforcing, and observing international law. In Article 3 subsection 1 of The Convention, the functions of the diplomatic mission is explained, which further gives us an insight into what modern day state diplomacy is about. It states thus;" The functions of a diplomatic mission consist inter alia as (a) representing the sending State in the receiving State; (b) protecting in the receiving State the interests of the sending /State and its nationals, within limits permitted by international law. (c)negotiating with the Government of the receiving State; (d) ascertaining by all lawful means conditions and developments in' the receiving State and reporting thereon to the Government of the sending State. (e) promoting friendly relations between the sending State and the receiving State, and developing their economic, cultural and scientific relations" Article 3 (1) of The Vienna Convention on Diplomatic Relations, Vienna, 18 April 1961

Through the functions of a diplomat as described by the Vienna convention on diplomatic relations above, one derives from them the clear definition of diplomacy as far as the International Treaties and International relations are concerned. In today's international arena, three main treaties govern diplomatic relations and thus define and govern traditional diplomacy. They're; The Vienna Convention on Diplomatic Relations - 1961, The Vienna convention on consular relations -1963 and The Vienna Convention on special missions - 1969.

Globalization is originally derived from 'globe' which evolves to the term globalize, which refers to the interconnectedness of an international network of economic, social and cultural systems. Globalization thus literally refers to the process by which businesses or other organizations develop international influence or start operating on an international scale.

Several scholars have given definitions of globalization, all not differing any much further from the literal meaning given above. In one instance, Globalization constitutes integration of National economies into the International economy through trade, direct foreign investment whether by corporations or multinationals, short-term capital flows, international flows of workers and humanity generally, and flows of technology (Bhagwati 2004,3).

On another account, it is defined as a progressive increase in the scale of social processes from a local or regional to a world level (Bayly 2002, 48-49). Globalization is a reality whose impact is felt in every part of the globe and every person on it, even though all feel this impact on a largely differing scale (Mazlish 1998, 387). 
Globalization increases interconnectedness on all spheres of life. It has increased the worldwide technology and the comprehensibility of fast, effective communication and consumption of information and approved products. It also brings closer and links cultures, economies, and international relations on different levels (Naim 2009,28-30).

Over the last quarter century, globalization has become particularly important. It is in this period that the emergence of a global economy and a communications' revolution has been witnessed on the largest scale. It is also at this time of the cold war that the end of a fundamental ideological division centrally affecting International Relations, which involved both the USA and a multinational entity of the Soviet Union whose core state was Russia, was realized (Jenson, De Sousa Santos,2018, 1-9). It was after the post-cold war era that the world witnessed a rapidly expanding globalization, involving increased technological, political, economic, and cultural interactions.

According to Beck, an influential sociologist who wrote a lot about globalization, he classified the term as a collective process through which sovereign national states are crisscrossed and undermined by transnational actors with varying prospects of power, orientations, identities, and networks (Beck 2000,3). Conceptualized like this, globalization has the potential to undermine a key idea in International Relations widely held by realists and neo-realists that all states are important. This view is undermined because; globalization involves various kinds of cross-border 'actors' also known as transnational or non-state actors.

Accordingly, Beck $(2000,11)$ argues that the process of globalization is characterized by the geographical expansion and advancement of international trade, which involves global networking of finance markets and the growing power of transnational corporations. Globalization has also resulted into the ongoing vast evolution of information and communications technology that kind of gives the universe one voice in demand of universal human rights and other things. This is realized in media coverage and various non state actors like the Human Rights Watch that has taken on the world in that sphere.

Globalization has also led to the emergence of a post-national, polycentric world politics, in which transnational actors like multinational corporations, non-governmental organizations and the United Nations are growing in power and number alongside governments. It has also led to global cultural industries and the question of world poverty. Globalization has also led to significant trans-cultural conflicts in one and the same place and global environmental destruction.

Globalization thus signifies the capability of reducing the importance of territorial boundaries and, theoretically, of government-directed political and economic structures and processes. Some of these problems can be resolved or curbed by 'reconstructing' the sovereignty of states and their boundaries through diplomacy; thus, a need to look at the relationship between globalization and diplomacy.

\section{Relationship between Diplomacy and Globalization}

Both globalization and diplomacy are international relations' aspects that are important in global politics and International Relations' discipline. These two concepts share a mutual necessity. While diplomacy can act as a means of interconnectedness with diplomatic agents being one of the actors who play an increasingly important role in globalizing the world (Borcan 2012, 32), globalization can provide the path for diplomacy's main purpose which is to avoid conflict and promote cooperation.

It should also be noted that, given the fact that foreign policy is experiencing a passage from geopolitics to global politics it will require enhancing, respecting and adapting international institutions guaranteeing the international rule of law under the responsibility of all nations (Borcan 2012, 16).

The difference between geopolitics and global politics is mild as one is interdependent and, or a branch of the other. Whereas geopolitics only focuses on the study of the relationships between separate countries and the importance of their politics on their geographical locations, Global politics simply refers to relations between nation states (countries) or issues relating to all such as environmental regulation to tackle global warming which requires international cooperation, or other major issues that require the attention of all world powers like the global financial crisis of 2008. Geopolitics therefore is a key area of global politics, as international relations affect it profoundly. 
Global politics can also be felt under the aspect of soft power; which refers to the ability to achieve your objectives through the attractions of your culture and political system. Take an example of China establishing 350 Confucius centers and promoting Chinese language in the last decade or so. This gets easier with the advancement of communication and technology which are all as a result of globalization. This too is an aspect of cultural diplomacy.

In this regard we see that the politics of the world has largely shifted from geopolitics where the geography was largely a determinant of the world politics to global politics where the international relations and politics are more diverse. Therefore, global politics has as a result become a tightening link between globalization and diplomacy.

It should however be remembered that geopolitics is still in existence; for example, the president of USA Trump's decision to build a wall between USA and Mexico to deter drug cartels from escalating in the US is a geopolitical decision. Kenya's decision to build a wall between its northern border and Somalia to combat terrorism is a geopolitical decision too. These two scenarios are categorized as geopolitics because it's the politics within the geographical location of those countries that pushed for such decisions. To uphold the rule of international law under such circumstances, cultural diplomacy, information and technology are to indeed play a great role (Held 2005,9). With globalization, a state's behavior towards its citizenry is no longer an exclusively internal matter (Beetham, 1998, 61-2) and the leaders' behavior is now shaped by the various external factors like persuasion of international and regional organizations, foreign donors and civil society organizations (Risse, 1999).

While analyzing the relationship between globalization and diplomacy, it is worth noting that although in some instances the differences these two possess can supplement each other, it's not always the case. In other instances, the differences are worth noting and they only point out the two concepts (of Diplomacy and Globalization) as distinct from one another- a discussion worthy of academic research input. It is therefore important to consider the significance of the disconnections the two concepts have as well as discerning the location of these barriers and disconnections because such is a pre-condition to an analysis of the relation between diplomacy and globalization.

Unlike globalization that has no specific and standard form of hierarchy, command and control which makes it an all-inclusive concept - pluralistic with a variety of actors in the mix, a strong image of hierarchy, command and control hangs over the world of diplomacy. Whereas a diplomat is answerable to the state, actors in globalization are all equal with no chain of command or hierarchy. A diplomat is commanded, and he is only expected to say what he has been told to at the right time.

Furthermore, whereas a diplomat must have some level of education and expertise, it is not the case with globalization. A global customer doesn't need any defined qualifications to pass across their information; they have no guidelines and command of saying what and when.

While dealing with diplomacy, the preference is for concentrating on what is doable as opposed to what is right (Maley 2008, 1-2). The end results are often shaped by a cautious sense of pragmatism with a profound recognition of the boundaries of action, whereas patience and discretion are prioritized over emotionalism and transparency (Maley 2008, 2).

Practically, the functions of diplomacy and the effects of globalization may be classified as distinct to one another. Diplomacy, on one hand, is often viewed as a guild activity with well-placed insider's distinguished from excluded outsiders. Thus, diplomatic skills are a type of knowledge possessed by a particular set of professionals and handed down through a long tutelage whereas globalization stands out from the later as being an open-ended way of looking at and navigating the world with a high degree of inclusiveness about whom and what is included in its structure and agenda.

It is important to note that globalization has in a way, altered the sovereignty and boundaries of states which raises the question of whether diplomacy too has changed and, or whether it is still needed at all. The effects of globalization on diplomacy like other disciplines of International relations are immense and can thus be discussed below. 


\section{Effects of globalization on Diplomacy}

Globalization has got its effects on all spheres of international relations, and thus it's no wonder that its effects have extended to diplomacy too. In this chapter, we examine the effects of globalization on diplomacy and answer our main research question on whether globalization has indeed changed diplomacy.

On whether Globalization has changed diplomacy, the answer is yes is that neither of the two aspects is static. However, globalization has only changed the methodology of diplomacy but not its fundamental nature. Diplomacy has always been about building, maintaining, and using relations, and this has continued to be the case even with the advent of globalization. However, the methodology of traditional diplomacy has been altered by globalization. Ideally, diplomacy requires sovereignty to function, but with the emerging of globalization as already discussed above, the sovereignty of states have been theoretically altered, and thus, the methodology of diplomacy to has changed.

With globalization, comes an easy and fast way of sharing information and involvement of non-state actors in diplomatic missions. Although this is not done officially, it ultimately still changes the traditional methods of diplomacy as we knew them. Thus, globalization may not have revamped the nature of diplomacy, but it has certainly altered something on which diplomacy is significantly based - the sending authority. Traditional diplomacy requires sovereignty to function.

In the past, before the current phase of globalization, states had the monopoly on sovereignty, whether that is in the area of communication or the economy. However, today, states have lost that monopoly, and non-state actors are more involved and have emerged as 'diplomatic agents' than before. These range from journalists, NGOs, civil society groups, among others. However, the fact that the states still value and consider the official statements of their diplomatic agents irrespective of the information and role played by the nonstate actors is proof enough that the nature of diplomacy has not been changed by globalization.

Information is key, but the focus should be on accuracy and reliability of such information for any successful diplomatic missions. The contemporary phase of globalization, which has created an unprecedented era of technological change, has led to a revolution in communication, which requires diplomats to be cautious and fast thinkers. We are past the era of diplomats communicating through bags of mails with a month's timeframe for a considered reply. Gone are the days when diplomats would plan trips and spend months on the way. In today's global village, information is received and sent faster than ever before. Trips are shorter than ever before. Thus, globalization has changed diplomacy in a manner that it acts faster than before.

Although the evolution of technology and quick communication might appear as making the diplomat's instant communication easier, diplomats should be cautious of this development and avoid over trusting this transformative effect of the latest technological gadget.

According to globalists, while multilateral diplomacy prevails, power initially shared among several nations, shall be gradually better distributed among less powerful nations as globalization speeds up (Daalder and Lindsay 2003, 16).In such circumstances, diplomacy is likely to be democratized, thereby empowering international actors by providing a voice to each of them in decision making for the sake of higher justice. The case of the North Atlantic Treaty Organization (NATO) and the United Nations in peacekeeping and peace enforcement on the globe is that of a multilateral democratized diplomacy. These organizations are a representation of multilateral diplomacy since they deal and negotiation for or on behalf of more than two countries, and they have acted as a voice for each of these countries, thus being democratized. UN peacekeeping mission in South Sudan-Darfur, for example, was done in the interest of other neighboring countries to which the instability would affect. On the other hand, being a voice of all those countries all together is a kind of democracy in diplomacy. All this is brought about by the interconnectivity of the world through globalization where it is not about a state anymore but a global entity.

With the outburst of the current phase of globalization, diplomacy is seen to have somewhat shifted from bilateral diplomacy to multilateral engagements because with globalization; there have emerged global threats that must be handled globally rather than unilaterally. Whereas bilateral diplomacy is aimed at branding a state's image and creating empathy for the respective state's policies, multilateral diplomacy 
focuses on the maintenance of international order and thereby bringing stability to the global arena. Because of the interconnectivity, multilateral diplomacy is now prioritized over bilateral diplomacy. We see multilateral diplomacy in a way Russia, Turkey, Iran, and the USA are trying to redraw peace in Syria. Because of the interconnectivity, the world cannot rely on bilateral diplomacy to create peace where it has been broken. The instability in Syria, for example, can spread instability in these other countries, not necessarily geographically but economically and other spheres. Thus, they need to come together and restore peace in Syria.

As a result of globalization, it can be argued that diplomacy is directing towards regionalized diplomacy in which international concerns are approached as a region. Nevertheless, bilateral diplomacy has remained crucial to explain and coordinate domestic policies (Henrikson 2005, 7). A case in point is the regionalized Arab Gulf diplomacy applied in the Yemen political crisis resolution process through the Gulf Cooperation Council (GCC) as the sole international institution powerful to represent a relevant actor for negotiations of any kind as compared to other western international institutions whose influence had proved unheard (Nonneman 2015).

Another example of regionalized diplomacy is where the Economic Community of West African States (ECOWAS) as a regional body negotiated the peaceful handover of the then president of The Gambia Yahya Jammeh to the current president Adama Barrow. ECOWAS further made agreements on the way forward and maintenance of post-election peace and stability in 2017 a move that identifies with diplomacy. All this was as a result of the economic interdependence and interconnectedness that has come as a result of globalization that has evolved in the West African states just like all other parts of the world.

Even in such scenarios as discussed above, it is no doubt that the activities and format followed through is bound to keep traditional etiquettes of diplomacy, since the role of these regional state actors is neither new nor necessarily something that undermines the position of traditional diplomacy. Accordingly, even with regional diplomacy, the core roots of traditional state to state diplomacy shall be maintained.

As discussed earlier, indeed technology like other forms of globalization has changed the method of traditional diplomacy, but it is unlikely to replace the primary endeavor and root of traditional diplomacy which is getting to know the 'other.' This entails building a relationship and cultivating that for national interests. Considering the unreliability of the non-state actors who perhaps might not be having interests of the state at heart, perhaps that's why even with the advent of globalization (for example communication), the states still consider the official communication from the official diplomats. This has somehow retained the nature of traditional diplomacy.

There are numerous effects of globalization on diplomacy, but those discussed above focused on state diplomacy. It is clear how globalization has, in some ways, changed diplomacy, but it has not replaced diplomacy in any way.

\section{Conclusion}

The ability to practice diplomacy is one of the defining elements of a state, and it is no doubt that diplomacy has been practiced since the formation of the first city-states or humanity itself as already discussed. Originally diplomats were sent only for specific negotiations and would return immediately after their mission concluded. Today, however, with globalization that comes with interconnectedness and easy access and receiving of information, permanent diplomatic residences and embassies have been established.

In the past, diplomats were usually relatives of the ruling family or very high rank to give them legitimacy when they sought to negotiate with the other state. This has not changed much since a diplomat must still be a trusted 'friend' of the sending state.

The current phase of globalization has created unprecedented progress of communication, information, and technology which has resulted into the interconnectedness of the global economy, political, and cultural aspects of states thereby making the means of movement of people and products easily accessible. As a result, non-state actors have emerged on the scene of global governance and diplomacy in both national and international levels. 
The non-state, like non-governmental organizations, multinational corporations, journalists, actors, have acquired a considerable amount of influence by putting to light global concerns and shortfalls of the state actors. This development is responsible for the recent evolution of the alteration of the methodology of diplomacy.

With the discussion above, it is safe to argue that the nature of old-fashioned diplomacy remains somewhat intact, and globalization has only affected and changed the methodology. If one only limits diplomacy to sharing of information, then there's no doubt in that way, globalization has changed diplomacy. However, it should be noted that diplomacy goes beyond the sharing of information. It should, however, be noted that the basics of the old-fashioned diplomacy go beyond sharing of information, they require knowing 'each other' through negotiations and other peaceful means. Such concepts are indeed still intact. Thus, globalization has only changed the methodology and conduct of diplomacy but not its nature as stated above.

\section{References}

Bayly, C. A. 2002. “A Archaic' and 'Modern' Globalization in the Eurasian and African arena, c. 1750-1850.” Globalization in World History, 47-73.

Beck, U. 2000. What is globalization? Cambridge: Polity Press.

Beetham, D. 1998. "Human Rights as a Model for Cosmopolitan Democracy." In: Archibugi, D. and D. Held and M. Koehler (eds.). Re-Imagining Political Community: Studies in Cosmopolitan Democracy. Cambridge: Polity Press.

Berridge, G. 2010. Diplomacy: Theory and Practice. New York: Palgrave Macmillan.

Bhagwati, J. 2004. In defense of globalization: With a new afterword. Oxford: Oxford University Press.

Borcan, A. 2012. "Diplomacy and Cosmopolitanism in a Globalized World." Journal of International \& Global Studies 4(1): $32-40$.

Campbell, F. 2015. "Has Globalization Changed the Nature of Diplomacy?" Proc. of Ethical Standards in Public Life, St. Edmund's College, Cambridge University, UK. Np, 20.

Colegrove, K. 1919. "Diplomatic procedure preliminary to the Congress of Westphalia." American Journal of International Law 13(3): 450-482.

Daalder, I. H., \& Lindsay, J. M. 2003. "The globalization of politics: American foreign policy for a new century." The Brookings Review 21(1): 12-17.

Held, D. 2005. "Globalization, international law and human rights." Available at https://opencommons.uconn.edu/cgi/viewcontent.cgi?article=1001\&context=hri_papers.

Henrikson, A. K. 2005. The Future of Diplomacy: Five Projective Visions. Netherlands Institute of International Relations 'Clingendael'.

Hill, G., \& Nonneman, G. 2011. Yemen, Saudi Arabia and the Gulf States: Elite Politics, Street Protests and Regional Diplomacy. , London: Chatham House.

Jenson, J., \& de Sousa Santos, B. 2018. Globalizing institutions: Case studies in regulation and innovation. London: Routledge.

Maley, W. 2008. Global governance and diplomacy: worlds apart? Springer.

Mazlish, B. 1998. "Comparing global history to world history." The Journal of Interdisciplinary History 28(3): $385-395$.

Naím, M. 2009. “Globalization.” Foreign Policy 171(March-April): 28-34.

Neumann, I. B. 2012. At home with the diplomats: Inside a European foreign ministry. Ithaca, NY: Cornell University Press.

Nicolson, H. 2001. The evolution of diplomatic method. University of Leicester.

Rie, R. 1950. The Origins of Public Law and the Congress of Vienna. Transactions Year, 36, 209.

Ryniejska-Kiełdanowicz, M. 2009. "Cultural diplomacy as a form of international communication." Institute for Public Relations BledCom Special Prize. dalam http://www. instituteforpr. org/wp-content/uploads/Ryniejska_Kieldanowicz. pdf [diakses 29 September 2014].

Risse, T. 1999. “International Norms and Domestic Change.” Politics and Society 27(4): 529-559. 